\title{
Women and the Scottish Clerks' Association: From Contempt to Collegiality
}

R. Guerriero-Wilson

I

This paper will trace the evolution of the attitudes expressed by the Scottish Clerks' Association (SCA) towards women in clerical work in the late nineteenth and early twentieth century. For women trying to establish careers in office work it was necessary to be accepted as colleagues by men in organisations like the SCA. But, as Sylvia Walby noted, explanations of the increasing presence of women in clerical work in the late nineteenth and early twentieth century have emphasised the role of employers as the main actors in the feminisation of clerical work, while the resistance (or acceptance) by male clerks has been given less attention.' The evolution of the SCA's attitudes illustrates such resistance and then the growth of a kind of acceptance of women clerks in the early twentieth century; but this acceptance was within the context of male clerks' attempts to restructure their occupational group in order to preserve the better jobs for themselves.

Clerical work as an occupation was ripe for restructuring due to the changes it was undergoing by the late nineteenth century. Earlier in that century, clerical work had been work mainly for men, in small offices, in close proximity to the owner of the firm. Men in clerical work would expect to support their families through that work, possibly to rise to become businessmen themselves, and to feel secure in their masculinity throughout their working lives. But by the end of the nineteenth century, the intimate, secure, small offices so often portrayed by Dickens were changing dramatically. Expanding enterprises in large-scale manufacturing, finance and transport required much larger offices and many more clerks than Dombey or Scrooge ever required. Even in small enterprises, increasing competitive pressures prompted greater attention to business decisions like costing and purchasing, and thus more thorough and careful record keeping and reporting were needed. In addition, a greater interest by the state in profitability and employment also created the need for increased record keeping and reporting. All of 
this meant that all enterprises required more clerks. With increasing size of clerical staffs came division of labour and bureaucratic hierarchies. Some clerks became managers at various levels; while at the bottom of the hierarchy work became increasingly routine, repetitive and low paid.

These latter jobs would eventually become almost entirely occupied by women. This happened for many reasons but largely because women were usually paid less than men. This advantage to employers was reinforced by marriage bars, formal and informal, that kept the lowest level jobs at the lowest possible pay rate through the constant replacement of experienced women by entry-level women. At the bottom of the clerical hierarchy a perpetually entry-level staff made economic sense, because the jobs were such that there was no value added by experience. And so marriage bars have been seen as a capitalist and patriarchal strategy to both keep labour costs low and to keep women in subordinate positions. ${ }^{2}$

Admittedly the cost savings of high turnover cannot be denied at the bottom of a clerical hierarchy. But at other levels of the hierarchy such employment practices require more careful scrutiny for they may not have been entirely economically rational for employers. In a social context where lower pay for women was accepted as normal, logical and reasonable it would have made economic sense to employ mature experienced women as senior clerks and middle managers rather than mature experienced men. ${ }^{3}$ There must, then, have been another motive for reserving this level of the office hierarchy for men. And so the reasons for marriage bars and a gender division of labour in clerical work must include, not only the wish to create a permanently low wage work force to do the routine clerical work, but also the desire to maintain well-paid 'men's work' within office hierarchies that would provide careers and self-respect for male heads of households. As Bennet has suggested, the large scale recruitment of women in the first half of the twentieth century was precisely so that a gendered hierarchy and division of labour could protect a class of better jobs and better job opportunities for breadwinners. ${ }^{4}$

The concept of 'separate spheres' can be seen to underlie many of these actions and strategies on the part of male employers and male heads of households attempting to protect a category of employment for themselves. Gordon and Nair speak of a "separate spheres" ideology" and an 'ideology' is what it was. The concept of separate spheres was not a description of nineteenth century social structure or gender relations but an ideal. It reflected the beliefs held about how gender 
relations ought to be - men ought to be in the public sphere and women ought to be at home. As such, the ideology of separate spheres and its 'vital cornerstone' of the 'ideal of the family wage' ${ }^{6}$ were powerful influences on the actors living in and moulding the late nineteenth century and early twentieth century workplace. The ideology of separate spheres was powerful because operating as an 'economic agent' in the public sphere was the foundation of masculine identity:

To become adult men within their own terms they must provide a livelihood which made possible a domestic establishment where they and their dependents could live a rational and morally sanctioned life. ${ }^{7}$

Kwolek-Folland has made a similar argument in the context of the United States - that the ideal of 'separate spheres' was linked to and may indeed have been the foundation of masculine identity. ${ }^{8}$ Davidoff and Hall argued that the whole concept of a salaried occupation within the public sphere evolved as masculine property. ${ }^{9}$ For male clerks, defining a segment of clerical work as 'man's work' through some form of female exclusion seemed especially important because the 'ambiguities about the masculine association of their jobs ... clean hands, polite speech, neat clothing, high standards of literacy, the indoor, sedentary nature of their work ... ran against the grain of masculinity'. ${ }^{10}$ The physical presence of ever more women in the public sphere of business, as male clerks defined their occupational area, was even worse. Women's presence made more difficult the already difficult task of preserving the idea of clerical work being 'man's work'.

As Witz has noted, other groups of men used professional status to protect themselves from the competition of women and the presence of women in 'their' jobs:

the relative ease with which middle class men had no need to fear female competition for many jobs was precisely because bourgeois men already had exclusive access to many institutional forms in modern society, like the university, professional associations and of course the state."

Of course clerks were a bit less bourgeois and a good deal less in control of society's institutions than the middle-class professionals Witz had in mind. Clerks' attempts to act as gatekeepers for their occupation were far less successful than those of the 'real' professions. ${ }^{12}$ Nonetheless clerks' claims to professional status and their attempts to exclude women from their occupational territory are noteworthy as attempts to carve out an occupational niche for breadwinners.

From the very earliest days of the Scottish Clerks' Association in the 
late nineteenth century the increasing presence of women in office work and the possibility that they might be admitted as members to the association was an issue that the Association's members could not ignore; though they did try. When forced to consider the admission of women they persistently refused. This refusal was strategic and symbolic, not simply stubborn; it represented the belief that the men of the SCA were in a different occupational category from the women flooding into clerical jobs. The SCA's reluctance to admit women was part of the Association's strategy to protect its members' interest in maintaining some clerical work as men's work. The breadwinning clerks who often described their work as a profession saw the transient and temporary female clerical workers as a separate occupational group. In doing so they were grimly holding onto a view of clerical work as high-status work, possibly because of the opportunities it was thought to offer. At one time male clerks might have hoped to rise to be owner/managers themselves, but as this possibility became ever more unlikely ${ }^{13}$ claims to 'professional' status and a 'career' in clerical work were what made this work remain appropriate work for male heads of households, despite the increasing numbers of women in the occupational group.

Only the legal changes brought to the workforce by the National Insurance Act of 1911 and the huge demands for more clerical labour brought about by the Act's implementation, finally forced the SCA to accept women members. From that time, through the changes to the clerical labour market brought on by the First World War, one can detect eventually what might appear to have been a fully collegial acceptance of women in clerical work and in the Association. But as this essay will explain, this acceptance was qualified in a way that maintained the separation between clerks who were breadwinners or careerists and those who were transient and temporary clerks. Over time, this became the important distinction for the SCA rather than the gender identification of particular jobs. Despite the apparent positive nature of this change the SCA's actions were still part of a process that defined the white-collar career in male normative terms that stressed commitment to the career and defined that commitment as long, continuous service without breaks. Women could be accepted as whitecollar careerists, but only if they accepted this definition of career.

\section{II}

The Scottish Clerks' Association had been called into being in response to clerks' need for a network that could provide introductions and references in job searches. A letter to the editor of the Glasgow Herald on 
1 March 1886 appeared under the heading 'Hard Times'. In it the author proposed to start a clerks' association along the lines of the Liverpool Clerks' Association that had been operating for more than twenty years. The purpose of the new association would be the same as that of the Liverpool clerks, 'To ensure members against loss through want of employment, sickness, old age and death, and to introduce to employers, free of charge, clerks of good business capacity and character.'

Once the Association was under way it established a 'situations register' that listed the names and qualifications of members available for work. Then the strategy was to build up a network:

the members now should make every effort to secure the interest of the heads of departments, chief clerks, secretaries, and managers in the Register, as with these gentlemen frequently lie the power of making a great number of the clerical appointments falling vacant on their respective staffs. ${ }^{14}$

The SCA also hoped that as the organisation grew 'employers and gentlemen holding better positions' would become members, or that members themselves would achieve better positions while remaining with the Association. Although it often seemed that the SCA functioned mainly as a provider of medical, unemployment and life insurance, in its earliest incarnation this other aspect, of building networks and establishing connections with well placed businessmen, was high on the agenda of the men who sat on the Association's committee of management.

Access to well-placed businessmen or even clerks in responsible positions would, it was hoped, improve the ability of individual clerks to develop careers for themselves. A career, as opposed to a job, would provide security, good pay, and status. And it may have been that by the late nineteenth century it was becoming clear that clerical work no longer automatically offered these things to a man. The formation of the SCA was thus part of what Gregory Anderson called the clerks 'search for security' ${ }^{15}$ in an occupational category which was rapidly experiencing lowering status, lower pay and higher turnover due to the routinisation, division of labour and general deskilling of much clerical work.

Building a network that would allow members access to desirable jobs required an understanding of and identity with the needs of employers. Members were constantly encouraged to recruit new SCA members, but with care. 'Put yourself in the position of an employer for the time being while you judge of the man's qualifications for admission. ${ }^{16}$ But the SCA did not act out of a sense of subservience to employers so much 
as a sense of identity with those above them on the ladder of success. In helping employers they also helped themselves by becoming part of the business community's network of reputation and trust.

And so the standards required for membership in the SCA were the standards that would help guarantee that a clerk was employable. As continuous employment was crucial to an individual's hope for success, it was also an important component in protecting the integrity of the SCA's reputation. The reasons for which individuals were denied membership were often the same reasons for which an individual would be turned down for a job. The health of the Association's insurance funds and the spotless reputation of the SCA were more important than an individual's problems. For the good of the whole the marginal must be rejected. Poor actuarial risks and the difficult-to-employ need not apply. Indeed, the figures on rejected applications show that proven employability was perhaps the most important criterion for membership. $^{17}$

However, the Scottish Clerks' Association also wanted their adult members to have made a commitment to the SCA early in their lives. A strong bias against older clerks existed in member selection. The Association accepted applications from men up to the age of fortyfive; that deadline was absolute. ${ }^{18}$ To be sure, the SCA courted the patronage of older, successful businessmen and encouraged long-time members to stay with the Association even after they had risen above the rank and file of clerks. The influence of such people could do the Association nothing but good. It was not age that the SCA was discriminating against in its age policy; it was lack of success. A man over forty-five who was still a simple clerk was not only a bad actuarial risk but he also had no contacts or connections with which to enrich the Association.

Women did not fit into the view of the SCA and clerical work that the directors of the Association held. Women could not share the aspirations of making a career for themselves or aspire to an executive position. Individual women in clerical work were generally long-term temporary workers and women as a presence in clerical work represented the beginnings of clerical workers as a permanent occupational group with little or no upward mobility. The SCA refused to acknowledge this as the nature of clerical work, clinging to the idea of clerks as 'professionals' on their way to better things, or at least hoping that clerical work could remain suitable work for male heads-of household. Keeping women out of the Association maintained their self-image of clerical workers as breadwinners. 
In general the subject of admitting women to the Association was only taken up when forced upon it. In 1887 the SCA's directors were moved to minute a comment on the large numbers of advertisements in the local press looking for 'female clerks', although no specific cause for concern was noted..$^{19}$ It would be a few years after this first mention of women clerks before the subject was dealt with seriously by the Scottish Clerks' Association. In 1895 'A Lady Typist' wrote to the SCA journal, the Clerks' Gazette, wanting to know if the SCA was open to women. Her letter was published along with letters from existing members who did encourage the typist to apply to the SCA. ${ }^{20}$

Unfortunately for women clerks there was less acceptance in the attitudes of the directors of the SCA towards women in the clerical workplace. In May of 1895 they received an application from a woman (possibly the Lady Typist correspondent) and held it over to be considered at some later date. When the subject came up again in July the directors decided to turn the matter over to the autumn meeting of the General Council in September. ${ }^{21}$ At that meeting, the Association's secretary, Thomas Berrie, gave the opinion that 'under the rules they had no power to admit lady clerks'. He admitted there was nothing that specifically excluded women, but 'from the phraseology employed in the Rules, it is to be inferred that it was not the intention of the framers of the Rules that lady clerks were to be admitted' ${ }^{22}$ Berrie appears to have interpreted the rules' use of only masculine pronouns to mean that the framers of the rules had actually considered women clerks and rejected their membership. Such an interpretation would seem to reflect Berrie's own hostility to women members rather than the probable intentions of the original members of the SCA.

But other participants in the discussion were explicit in their dislike of women clerks. One said, 'The tendency of the ladies would always be to accept the salary offered, and there could be no competing with them. This would give rise to considerable unpleasantness.' But again, this sounds more like prejudice than reason. Other reasons were also offered for not admitting women and in the end it was decided that the woman who had applied for membership four months earlier was to be told that 'the Constitution does not allow of lady clerks being admitted'. This solution was unanimously adopted. ${ }^{23}$

A few years later the subject of the admission of women to the SCA again came up and was dealt with at the autumn meeting of the General Council in 1899. The speaker at the meeting felt women should remain excluded from the SCA on the basis that their membership would only be temporary and what the Association wanted was 'members in whose 
commercial prosperity we should always feel called upon to take a deep interest ...', although he admitted that life long, committed members were rarely what they got in most of the men they admitted to the Association. Still, that was what they should be getting and so they should not even consider women. ${ }^{24}$

The speaker further argued that should the SCA admit women it could then be accused of aiding and abetting the tendency of women in clerical work to reduce wages for all clerks. He considered that women clerks were 'most dangerous competitors' because 'not being breadwinners, the call upon their purse is of necessity confined to themselves' and so they would work for wages far lower than those required by men. He went on to say that they probably put up with the low wages and the vicissitudes of clerical work because they hoped soon to be 'happy mistresses of their own home, where they anticipate living in uninterrupted domestic joy far removed from the worry inseparable from commercial pursuits'. He further accused women clerks of ruining the livelihoods of those upon whom they were likely to depend to support their domestic bliss. His speech does seem to reach the level of tirade in laying the blame for low clerical wages at the door of women in clerical work. No thought that employers might be exploiting women workers appears to have been entertained. Instead, the idea expressed was that it was entirely women's fault that their labour was so little valued and that their pay was so low. ${ }^{25}$

The discussion that followed the speech was slightly more moderate in tone but it reflected only a reluctant acceptance of the fact that women clerks were there to stay and the SCA should make the best of a bad situation. Other comments suggested that if women were such dangerous competition then they should be brought within the Association in order to 'control competition and maintain salaries' ${ }^{26}$

In the end the Directors (by then called the Committee of Management) again decided 'admission of Lady Clerks to membership in the Association was impracticable, and would not be favourably regarded by the general body of male clerks and on this account the proposal should not be entertained'. ${ }^{27}$ Nor did the subject appear to come up again for the remainder of the first decade of the twentieth century.

It is difficult to know how the 'general body of male clerks' in the SCA would have regarded the admission of women as members but the expressions of welcome and encouragement in the 1895 Clerks' Gazette suggest that at least some men saw women as due an equal chance to make a living. The problem was with the men at the top of the SCA, who wanted to regard themselves as professionals and on a par with 
lawyers and accountants. A segment of the workforce that was almost solely temporary and thus constantly changing and disproportionately young and poorly paid could not possibly fit their image of professionalism; but that image represented an unrealistic aspiration. Clerks, even head clerks, lacked control of a valuable and unique area of knowledge and exercised no real gatekeeping function to the occupation. But at the time the status of 'profession' had not been so well analysed and delineated as it has since been. Many clerks believed themselves to be professionals, believed professionalism to be the key to a secure, breadwinning career, and believed that the influx of women into clerical work was the main threat to their status. Such beliefs were what motivated their actions. Subsequent realities did not. And so it may not have been misogyny as such that moved the Committee of Management of the SCA repeatedly to refuse the admission of women but simply the fact that women's work patterns placed them in a separate category of occupation from the lifelong 'professional' careers that the leaders of the SCA envisioned for themselves.

However, events would overtake the men of the SCA. In particular, clerical work would be forever changed in a number of ways by the introduction in 1911 of National Insurance. This development in government/business relations would, for one thing, create a new and massive financial enterprise. The record-keeping requirements were vast. Not only was it necessary to create a government agency full of clerks to administer the scheme, but also many employers found it necessary to hire more clerks to keep track of their side of the enterprise. Prior to the Act the payment of wages need only be recorded for internal use - to know who had been paid in a particular week, to know what rate someone was being paid, or when their last raise had been. With national insurance, wage payments had to be added up, the employer contributions calculated, reports drawn up and payments made. Given the pen-and-paper technology of the day it was a stunningly ambitious undertaking. It was also one of the biggest clerical job creation schemes ever implemented. The Scottish Clerks' Association estimated that,

the demand for clerks by the various Commissions, Insurance Committees, Approved Societies, and large employers of labour in 1912, in connection with the management of the National Insurance Act make the year an exceptional one. Little short of 10,000 clerks have been permanently employed in working the Act. ${ }^{28}$

All of these new jobs meant more jobs for women as well as men. 
However, it was not just numbers that finally forced the SCA to admit women. It was the legal requirements of the Act itself. National Insurance was to be administered, not just by the state, but also by the existing network of friendly societies throughout the country. The Scottish Clerks' Association functioned largely as a friendly society and so it was necessary for it to seek to be classified as one of the governments 'approved societies' or to lose much of its relevance to its members.

Right up to the moment when the National Insurance Act became law the SCA continued to ignore women as likely, or even possible, members. In the annual report issued in mid-1911, an article on the probable introduction of National Insurance mentioned the need for the SCA to increase its membership from the then current 6,500 to 10,000 in order to qualify for 'approved society' status as an administrator of the Act. But it never appeared to occur to anyone that one quick way to increase the membership was to invite women, who needed to belong to some society to administer their benefits, to join. ${ }^{29}$ This was despite the fact that by the 1911 Census the occupational category 'commercial clerk' was defined as $40 \%$ female in Scotland (24\% in England and Wales). ${ }^{30}$

At the twenty-fifth anniversary celebrations of the SCA in September of 1911 the speeches still addressed the 'young business men among us today' and urged the members to encourage 'every boy who enters an office' to join the Association. ${ }^{31}$

A special conference the day after the celebrations considered the likely effects on the Association of the National Insurance Act. The Chairman of the Association's Directors seemed to think that success had been achieved by the SCA in cooperation with other friendly societies in getting the 'approved society' minimum size reduced from 10,000 to 5,000 . But an effort to have the SCA and its members altogether exempted from the requirements of the act had failed. ${ }^{32}$ And so reluctantly the chairman noted the many changes that the National Insurance would bring to the SCA's constitution, including 'almost certainly, provision for lady clerks to which many of us have always been opposed'. ${ }^{33}$

In the discussions following the Chairman's address one of the members of the Association seemed resigned on the question of admitting women. The sense from this individual was that National Insurance was coming whether they liked it or not and so they had best make the most of it: 
Circumstances and system are altering [companies'] methods of business, and girls will be required to be considered. Why should the SCA not make provision for lady clerks who must insure under the Bill? Like other organisations we must make amendments to suit the changed conditions, and we must make the most out of the Bill we can. ${ }^{34}$

The motion to admit women to the SCA was first tabled and sent to the various branches of the Association for approval at the end of November 1911. The resolution to admit women to the SCA was finally passed on 28 December 1911. The application for 'Approved Society' status for the Scottish Clerks' Association was made to the Government the following week. It was clear that women were only being admitted in order to have the SCA administer their national insurance benefits. Their entry to the Association was only for what the SCA called the 'Sickness and Medical' benefits. Women were not offered out-ofemployment insurance, life insurance, or any of the other benefits that the SCA operated for its members. ${ }^{35}$

Even after the admission of women, hostility to their presence in clerical work in general was still expressed at the 1912 meeting of the General Council. ${ }^{36}$ Even in brief reports from branch agencies like Dundee, the agency representative felt it necessary when reporting their first application from a woman to add that 'although they did not believe in them. That, however, would not prevent them from doing their utmost to enrol them.' ${ }^{37}$ The Manchester branch representative ${ }^{38}$ reported that 'he believed they had lost time in not taking up the question of the admission of ladies years ago. The matter was being forced upon them now, and if they had admitted them before, he considered they would have been in a stronger position today. ${ }^{39}$ And that is perhaps the main point. Having aggressively ignored the issue of the growing numbers of women in office occupations over the years, the SCA was left in a position of being forced to admit women without preparation and on the terms of the Government's National Insurance Act. This would scarcely have fostered a welcoming attitude.

But by 1912, women were at least in the SCA. The first applications appear to have been made and accepted as early as March of that year. The annual report for 1912 shows an overall increase in membership of over 17,000 of whom approximately 3,500 were women. ${ }^{40}$ But the tone and self-image of the Association appear to have been unchanged simply by the addition of women to the membership rolls. In 1913, the opening address to the annual meeting of the General Council talked about clerks working together to help one another and 'to succour the widow and the orphan'. ${ }^{41}$ They were still appealing to the family bread- 
winner as their most natural constituent.

It was not until the whole nature of the workplace and society had been changed by the beginning of the first World War that some change in attitude appears to have occurred, although the extent of change can be questioned. At the 1915 meeting of the General Council the chair addressed the meeting on 'Women and their Work'. He appeared to believe that the prejudice against women in offices had 'entirely broken down'. But he went on to ask delegates to agree 'that none of the members of this Association would do anything to stop women from being employed as assistants in any office ${ }^{{ }^{42}}$ The claim that there was no prejudice may have been a hope rather than the reality. Why else would there have been a need to ask delegates not to behave in a prejudiced manner?

As the country looked forward to the end of the War and the return of men to domestic occupations the chairman of the general council noted it 'astonishing with what success women have come forward during the War and applied themselves with ability in places where formerly they were restricted to shorthand note taking and typewriting'. But this compliment, backhanded as it was, was only made in the context of warning men that they had to prepare themselves to do more than 'write and account'. He recommended they learn foreign languages, that they learn more about the general running of their company and that they learn more about sales and promotion. ${ }^{43}$ In such exhortations the Chairman appears to have been trying to carve out new occupational territory for men in office work. There is a sense of abandoning to women whatever women can do and finding something 'better' for men to do. Women's being able to do men's work just as well as men simply meant the work was not men's work anymore. The women had certainly not achieved equality.

It was also during the War that advances were finally made in providing additional insurance plans to the women members. By 1918 the Association felt it had enough information on women's employment as clerks to be able to calculate what their premiums and benefits should be for out-of-employment benefit or the special medical insurance that allowed for use of one's own physician. ${ }^{44}$ Of course, this extension of benefits had only been possible because the Association had been forced to accept women. The argument against their entry had often been that there was not enough information on their employment patterns to calculate insurance risk, but without their being members, the information could never be accumulated. Even so, they were offered less advantageous terms for the additional insurance benefits. 
In time, though, it seems to have been through the demographic and social changes brought about by the War that some women could finally begin to be seen as colleagues and not a lesser kind of clerk doing women's clerical work. In the course of the research for extension of benefits for women members the SCA quoted a leading 'Insurance Expert' who felt that circumstances had changed for working women. 'Owing to the mortality due to the war, liabilities for children and others have been cast upon them ... In these circumstances the necessity arises of providing for the future, and it may be for dependents in the event of death ...' His conclusion was that there was no reason to charge women higher premiums or not offer them various forms of insurance. ${ }^{45}$ Implicit in this assessment, however, is the belief that sole responsibility for a family is what gave a woman any kind of equality with a man. It was breadwinning and not the nature or quality of the work being done that was the deciding factor in attributing worth. And so implicit in this also is the sense of there being two kinds of women - those who were dependent on a breadwinner and those who were breadwinners, or surrogate men, themselves.

This is not to say that the War created these two categories of working women. As Gordon has indicated, the 1911 census showed thousands of women who were not dependent on a husband. Many were young and still living at home and thus presumably still dependent on their fathers, but many, many others were mature women who were single, widowed or deserted and often they were the primary carers and providers for children and elderly parents. ${ }^{46}$ So the phenomenon of woman as breadwinner was nothing new in 1918. It is just that the War likely increased the numbers, the visibility, and society's awareness of such women.

Still, such women were a special category - not normal. And it is this sense of a different kind of woman that seems to be the basis of any kind of collegiality in the SCA. When the SCA's General Council welcomed its first woman in 1921 she was, as far as can be determined, a widow. The Chairman offered what seemed genuine welcome in his claim that a woman 'must now be considered a permanent member of the profession, and one whose interests cannot be divorced from those of her male colleague'. ${ }^{47}$ Even more indicative of the acceptance of particular women as real colleagues was the focused appeal some years later to the independent woman, in charge of her own home and destiny. An SCA circular of December 1929 reported to its members the story of a 'clerkess' who had committed suicide because of 'worry over work, no home'. With this grim example the women of the SCA were warned: 
... no clerkess, no typist, or other lady professional or administrative worker, is 'all right' to-day. It does not matter how safe their posts may appear; or how clever and indispensable they think themselves; or how comfortable they may find their homes. No one is safe unless it is an insured safety.

Women were encouraged to 'make provision for a decent burial when that last sad event occurs'. ${ }^{48}$ There could be no clearer indication that the members of the target audience for this appeal were independent women without family to rely on. Nowhere in the piece is there any mention of marriage as something that might have saved the unfortunate 'clerkess' or any of the women readers. She and they were considered their own breadwinners. As such the appeal to them was couched in the same language the Association had always used in addressing the male breadwinners who, at one time, were its only members. More than thirty years earlier the clerks of the Association had been told 'There is no clerk ... from junior to manager, whose situation is lifelong, however secure it may seem'. At that time clerks were counseled to be provident as that is what would secure their 'independence built upon self-respect and self-reliance'. ${ }^{49}$ Taking responsibility for one's future security had long been the sign of a serious and 'professional' clerk as far as the SCA was concerned. By the late 1920 s women were at last acknowledged as being capable of that same independence and self-reliance.

By 1936, the fiftieth anniversary of the SCA, the Association's specially commissioned history was very explicit in making the distinction between two kinds of women in clerical work. There were 'the girls [who] regard an office career as the interval between leaving school and getting married'. And then there were '... the men, and ... the women over thirty-five, who have made their profession their life's work' ${ }^{50}$ There is no suggestion from the author that this latter group were a threat to the dimly persisting wish of the SCA to see its occupation as a profession, or even a threat to the men hoping to keep themselves and their families on a clerk's pay. The mature career woman (not 'girl') was a partner in the difficult job of maintaining the status and pay of their occupational group. Although the author's expression of acceptance towards mature career women comes from 1936, seemingly a long time after the original rejection of women members, in 1936 Thomas Berrie, the SCA secretary who had so diligently opposed women's membership, was just six years into his retirement. The author of the SCA's history was only the next generation of SCA management after those men who had so strongly rejected women members. 


\section{III}

Overall, the evolution of the attitudes of the SCA, from rejection, to unwilling acceptance to true, if limited, collegiality is not simply a story of 'progress' for women. For one thing, the rejection of women had never been universal. Some members of the SCA had seemed willing to accept women as colleagues very early in the organisation's development and so this story is not simply about a universally contemptuous male attitude evolving into an enlightened and accepting one. One might even say that the rejection of women by the more powerful men in the SCA was not about the rejection of women as women. It was more about men using the power of their positions to try and make the rules about what would be valued in clerical work. The world of work in offices was changing in the late nineteenth and early twentieth century. Men had lost the old certainties and securities that had allegedly gone along with nineteenth-century clerical work. The rejection of women clerks was a rejection of a new way of viewing work. It was rejecting the casualisation of clerical work by attempting to assert the importance of continuous, unbroken, long-term employment as the standard of high quality work.

But on the other hand, when women were accepted on these terms, it was not acceptance of women as women, with their uniqueness and their different life paths. There was a price to be paid. As KwolekFolland has said of women who wanted to be managers in the life insurance business, they 'had to adopt male business values and behaviors defined as male - to become like a man'. ${ }^{51}$ In a similar way, the collegiality offered by the SCA was not true collegiality for it accepted only those women who would reject one aspect of women's dual life roles and present themselves as surrogate men.

\section{Notes}

1. S. Walby, Patriarchy at Work (Cambridge, 1986).

2. See, for example, Walby, Patriarchy at Work, p. 154.

3. See, for example, S. Rose, Limited Livelihoods: Gender and Class in Nineteenth Century England (Berkeley, 1992), pp. 23-4 for a discussion of the belief that women should be paid less than men and the extremely longstanding nature of those beliefs. For Scotland, see E. Gordon, 'Women's spheres', in W. Hamish Fraser and R. J. Morris (eds), People and Society in Scotland, v II 1830-1914 (Edinburgh, 1990), pp. 209-14 on the generality of women's low wages in all occupations.

4. R. Bennett, 'Gendering cultures in business and labour history: marriage bars in clerical employment', in M. Walsh (ed.), Working out Gender: Perspectives from Labour History (Aldershot, 1999), p. 194.

5. E. Gordon and G. Nair, 'The economic role of middle-class women in Victorian Glasgow', Women's History Review, 9 (2000), p. 791.

6. Ibid.

7. L. Davidoff and C. Hall, Family Fortunes: Men and Women of the English Middle-Class, 1780-1850 
(London, 2002, 2nd edn), p. 229.

8. A. Kwolek-Folland, Engendering Business: Men and Women in the Corporate Office, 1870-1930 (Baltimore, 1994), p. 187.

9. Davidoff and Hall, Family Fortunes, p. 267.

10. Ibid., p. 269.

11. A. Witz, Professions and Patriarchy (London, 1992), p. 35.

12. R. Guerriero-Wilson, Disillusionment or New Opportunities? The Changing Nature of Work in Offices, Glasgow 1880-1914 (Aldershot, 1998), pp. 96-9.

13. R. Guerriero-Wilson, 'Office workers, business elites and the disappearance of the "ladder of success", in Edwardian Glasgow', Scottish Economic and Social History, 19 (1999), pp. 55-73.

14. Scottish Clerks' Association [hereafter SCA], Clerks Gazette, March 1895, p. 33.

15. G. Anderson, Victorian Clerks (Manchester, 1976), ch. 5.

16. Glasgow, Business Records Centre [hereafter BRC], Scottish Clerks' Association papers, UGD 303/2/1, Report of the Autumn Metting of the General Council, 1904.

17. BRC, UGD 303/1/5-7, Minutes, 1896-1902. Figures compiled in Guerriero-Wilson, Disillusionment or New Opportunities?, p. 161.

18. BRC, UGD 303/1/7, e.g. Recruitment circular, 1901, and elsewhere.

19. BRC, UGD 303/1/2, Minutes, 19 November 1887.

20. SCA, Clerks' Gazette, April 1895, p. 52.

21. BRC, UGD 303/1/5, Minutes, 11 July 1895.

22. BRC, UGD 303/2/1, Report of the Autumn Meeting of the General Council, 1895.

23. SCA, Clerks' Gazette, September 1895, p. 103.

24. BRC, UGD 303/2/1, Report of the Autumn Meeting of the General Council, 1899.

25. Ibid.

26. Ibid.

27. BRC, UGD 303/1/6, Minutes, 22 March 1900.

28. BRC, UGD 303/2/2, Annual Report, 1913, p. 7.

29. BRC, UGD 303/2/2, Annual Report, 1911, p. 13.

30. 12th Decennial Census of Scotland, 1911; Census of England and Wales, 1911. There is no certain explanation for the higher proportion of women in the clerical workforce in Scotland than in England and Wales, but it was likely attributable to two factors. Scotland's much longer tradition of basic education for all children meant that the literacy necessary for clerical work was as common among girls as boys. And also, at the turn of the century, especially in Glasgow, there was highly skilled, well-paid, well-respected work available for men in the shipyards and ancillary manual trades. Contemporary sources provide evidence that good manual jobs in the shipyards were considered the best jobs for a man. Men's preference for these forms of manual work and the large number of such jobs in the shipbuilding capital of the world, would have left more clerical jobs available to women. See e.g. H. McShane and J. Smith, Harry McShane - No Mean Fighter (London, 1978), pp. 74, 88.

31. BRC, UGD 303/2/2, Special Report: Semi-Fubilee Celebration/National Insurance Bill and Special Provision for Clerks, 1911 , p. 4.

32. Ibid., p. 9.

33. Ibid., p. 10.

34. Ibid., p. 11.

35. BRC, UGD 303/1/11, Minutes, 28 December 1911, 6 January 1912.

36. BRC, UGD 303/2/2, Report of the Annual Meeting of the General Council, 1912, p. 3.

37. BRC, UGD 303/2/2, Report of Abbreviated Meeting of the General Council, 1911, p. 5.

38. Although the SCA had started as a Scottish organisation (solely Glaswegian, in fact) its members did not always remain in Scotland. But though they migrated and immigrated they often sought to maintain their connection with the SCA. In some cases this resulted in branches of the SCA being established in English cities. The branches then provided networking bases for other Scottish clerks moving to new cities.

39. Ibid., pp. 5-7.

40. BRC, UGD 303/2/2, Annual Report, 1912, p. 6. The Annual Report does not actually record 
the number of women members but it can be deduced from the fact that of the 17,000 new admissions in 1912, approximately 11,500 had joined solely for the purposes of securing a society to administer their National Insurance account. The report further mentions that 8,000 men had joined solely for this purpose; therefore the remaining 3,500 must have been women since this was the only purpose for which they were accepted as members.

41. BRC, UGD 303/2/2, Report of the Annual Meeting of the General Council, 1913, p. 3.

42. BRC, UGD 303/2/3, Report of the Annual Meeting of the General Council, 1915, p. 3.

43. BRC, UGD 303/1/15, Report of the Annual Meeting of the General Council, 1917. Inserted in Minutes, 31 May 1917.

44. BRC, UGD 303/1/16, Minutes, 7 February 1918.

45. Ibid.

46. E. Gordon, Women and the Labour Movement in Scotland 1850-1914 (Oxford, 1991), p. 32.

47. BRC, UGD 303/2/3, Report of the Annual Meeting of the General Council, 1921.

48. BRC, UGD 303/1/31, Members circular, 1929.

49. SCA, Clerks Gazette, December 1895, p. 1.

50. R. Calder, A Fanfare for the Future (Glasgow, 1936), p. 11.

51. A. Kwolek-Folland, 'Gender, self, and work in the life insurance industry, 1880-1930', in A. Barron (ed.), Work Engendered (Ithaca, 1991), p. 189. 
Copyright of Scottish Economic \& Social History is the property of Edinburgh University Press and its content may not be copied or emailed to multiple sites or posted to a listserv without the copyright holder's express written permission. However, users may print, download, or email articles for individual use. 